\title{
Correlations between delayed fluorescence of chlorophyll, metabolism and yield of plants. III. Influence of viral infection on field plants and new technology of clone selection of virus-free planting potato
}

\section{Armen B. Avagyan}

Research and Industry Center of Photosynthesizing Organisms, Feed Additives and Physiologically Active Compounds, Yerevan, Armenia; armin.av@hotmail.com

Received 22 April 2010; revised 28 April 2010; accepted 8 May, 2010

\begin{abstract}
At the end of potato plants vegetation virus infection induced both decrease in maximum amplitude of delayed fluorescence maximal amplitude and increase half time of its decrease, as well as reduction in the amount of stems, plants' height and assimilation area surface, yield, acceleration of plants development and their early die-off. The differences of DF parameters and yields between strongly and weakly infected plants increase in case of a combined virus infection. In industrial test of the selection of virus-free planting potato by the use of DF parameter, a rise in the yield and decrease degree of viral infection of crops was obtained.
\end{abstract}

Keywords: Potato; Delayed Fluorescence Of Chlorophyll; Virus; Phonological Stage; Yield; Clone Selection; Virus-Free Planting Potato

\section{INTRODUCTION}

About 20 viruses cause diseases of potato and these diseases are one of the major causes of the potato yield reduction [1]. The most widespread and harmful potato virus of mosaic group (X, S, M (PVX, PVS, PVM)) can reduce yields from $5 \%$ up to $40 \%$, others, such as potato leaf roll virus (PLRV) or combined infections of potato viruses $\mathrm{X}$ and $\mathrm{Y}$, cause yield losses up to $90 \%[1,2]$. Furthermore, damage of metabolism and decrease in potato productivity are much greater in case of the combined virus infection in comparison with single-virus diseases [1,2]. What is most important: when the virus-free seed potato of this reproduction is used, plants of the first reproduction are infected in the current of vegetation, and in following reproductions the infected plants quantity progressively increases which correlates with the reduction of crops. This progressively increases rate of viral infection and its effect on yield rice in hot climate $[1,2]$.

In practice, virus-infected plants cannot be "cured" $[1,2]$. At present level of virus-free seed potato output via tissue culture has not so far managed to address the global solution of the problem connected with virus-free industrial production. Indiscriminate production of virus free seed can be undesirable and costly [1]. The prime cause of this is the lack of a well-developed elite seed farm designed to produce a necessary quantity of virus-free seed potato in many countries. As a whole selection technique should combine high sensitiveness with simplicity of application and low cost [1]. For virus-free planting tubers selection microprecipitation, although least sensitive, compared with latex and ELISA tests, is useful when laboratory facilities are not available to conduct the other tests [1]. Both microprecipitation and latex test may show non-specific flocculation to sap components other than the target virus [1]. Our research results showed that at the latex serological test preferred for virus diagnosis are less reliable for industrial virus-free seed potato selection in field condition, which has also been agreed with the data presented by other researchers $[3,4]$. The accuracy in serologic analyses was relatively higher for bud and flowering stages of potato plants [2-4]. However, it seems not reasonable to use the analyses results of these periods for clone selection of virus-free seed potato in harvesting period, since the new infection risk at the end stage of vegetation is high [2].

Currently, many countries have to export virus-free potato planting tubers, although this is likely to increase 
the domestic production cost. Over and above, problems concerning small industrial sowings (farms, etc.) that do not have a constant access to virus-free seed potato as well as laboratory facilities for the serological diagnostics of viruses. In the meantime, these farms may be one of the greatest reasons for the spread of virus diseases. The selection of preventive measures against viruses requires labour input and, therefore, the development methods for mass selection of virus-free seed potatoes for planting are of great importance.

Virus infection also led to a decrease in plants' photosynthetic potential resulting from the reduction in their assimilating surface square, photosynthetic rate, ribulose-1, 5-diphosphate carboxylase activity, contents of chlorophylls and xanthophylls cycle pigments, and concentration and activity of PSII [2,5-8]. As the disease developed, the maximum carboxylation velocity of ribulose-1, 5-diphosphate carboxylase and the maximum electron transport rate contributing to ribulose-1,5-diphosphate carboxylase regeneration gradually decreased, followed by substantial reductions in the relative quantum efficiency of PSII electron transport, the efficiency of excitation energy capture by open PSII reaction centers [6]. It was assumed that viral infection depressed photosynthesis mainly by interfering with the enzymatic processes in the Calvin cycle, which resulted in a down-regulation of electron transport [6].

PSII is the main producer of DF (the intensity of the PSI DF is several times lower [9]), which possesses raised sensitivity to the action of plant metabolism changes and various environmental factors. DF transients have been shown to be driven by many mechanisms, including electrical and $\mathrm{pH}$ gradients [10], acceptor availability, donor availability [9], and redox state of the oxygen-evolving system [11,12]. DF induction curve, registered in a several minutes time period, encompasses two major phases - a fast one, taking place in the first second of induction, and a slow one, that can last for minutes (Figure 1). Each phase is shaped by several processes running at the same time $[11,12]$. When applying the phosphoroscope-based method of registration, the maximum intensity of leaf DF curve (I, fast phase), the phases of which many authors attribute to the changes of the electrical potential, depending on the size of ECP on a membrane on the state of the PSII reaction center, since the light induced potential difference and the proton gradient across the thylakoid membrane are thought to reduce the amount of activation energy necessary for the back reaction between $\mathrm{QA}^{-}$and $\mathrm{Z}^{+}$to occur and on the other hand, the I level follows the extent of the variable component of fluorescence and has been suggested to be proportional to the amount of oxidized QA at the beginning of illumination [10-12], as well as the concentration of active centers of the PSII $[13,14]$. Previously, it was assumed that the time course of DF

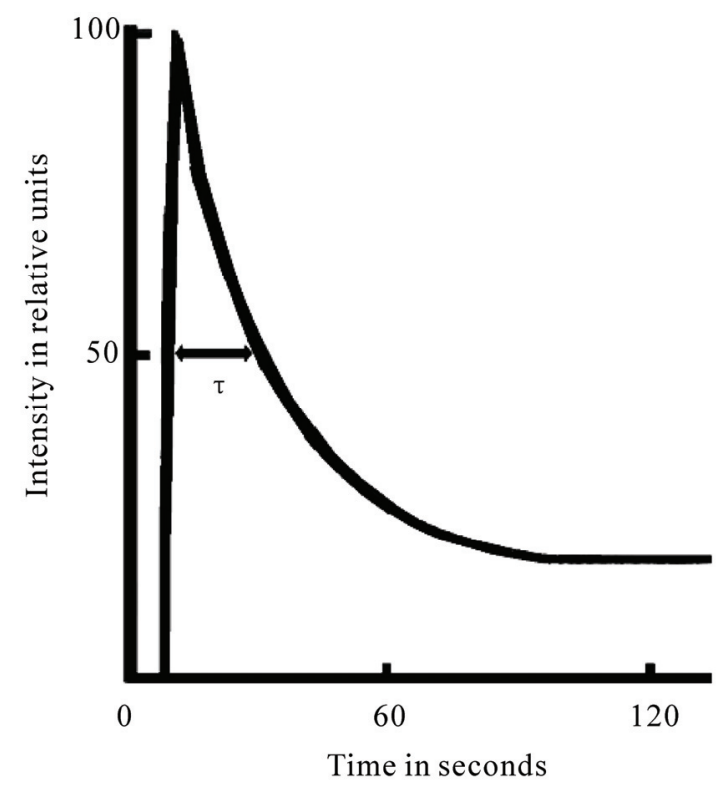

Figure 1. Induction curve of delayed fluorescence of chlorophyll.

after the maximum is possibly influenced by a number of DR (directly or indirectly modifying the characteristics of PSII) [11,12]. The decay of induction curve was generally explained by a decrease in the membrane energization as a result of secondary cation efflux from thylakoids $[11,12]$. Our results showed that half time of I decay $-\tau$ describe the level of interaction LR and DR of plants $[13,14]$.This is a biological base triggering the use of these DF parameters in physiological research. The interest of using the parameters of this luminescence for the diagnosis of plants' state is identified also by the possibility of their fast measurements on intact objects by the use of comparatively simple and accessible equipment. Thence, our goal was to research the effects of viral infection influences on potato plants by the use of DF parameters as well as to develop new method for selection of virus-free planting potato.

\section{MATERIALS AND METHODS}

\subsection{Plant Material and Experimental Design}

The Industrial Test objects were the potato (Solanum tuberosum) of following varieties: Pirmunes and Domodedovskiy (tubers planted on March 30), Byelorussian Early (tubers planted on March 30 and July 12, two-harvest culture per year) planted in dry and hot climatic conditions of the Armenian Ararat Valley, and variety Lorh, the tubers of which were planted on May 5 in the temperate climate of the Sevan basin.

\subsection{Measurement and Sample Protocol}

The degree of infection among potato plants (the viruses 
$\mathrm{X}, \mathrm{S}, \mathrm{M}$ and $\mathrm{Y}$ ) was determined in bud and flowering stages through the latex serological test $[1,2]$ by the use of the serum, produced in the Russian Potato Research Institute.

The parameters of DF induction curve of the leaves without virus infection symptoms were measured from the center of lobes by using a single-disc phosphoroscope (time period between excitation and recording of DF was $7 \mathrm{~ms}$ ), exciting light was obtained from a $200 \mathrm{~W}$ glow lamp (KGM-200, provided maximum intensity of modulated visual light at the sample surface of 2000 $\mu \mathrm{mol}$ photons $\mathrm{m}^{2} / \mathrm{s}$ ) and photodiode at temperature of $22^{\circ} \mathrm{C}$. Each detached-from-leave lobe was incubated about 1.5 hour in the dark between paper sheets at temperature of $22^{\circ} \mathrm{C}$.

\subsection{Statistical Analyses}

The data were processed from a mathematical standpoint by using the Student's and Fisher's exact test, with $5 \%$ significance level, as well as based on the standard methods of correlation analyses.

\section{RESULTS}

Significant differences of DF parameters between strongly (variants A) and weakly infected variants (variants B) were observed only at the end of the plant vegetation period (Table 1). The plants of the variety Domodedovskiy of the variant A had a low height by $20 \%$, less stem amount by $28 \%$ per shrub and a productivity reduction by $29 \%$, in comparison with the plants of the B. Correspondingly, for the plants of the variety Byelorussian Early of the variant $\mathrm{A}$, these indicators were lowered by $7 \%, 28 \%$ and $27 \%$ as compared to its variant $\mathrm{B}$.
In conditions of the Ararat Valley the plants of the variant A of the variety Domodedovskiy achieved the full seedling stage at 3 days earlier, and the full bud and flowering stages at 4 days earlier as compared to its variant B. In temperate climate of the Sevan basin, the beginning of the full phenological stages of variant $A$ was at 2-3 days earlier, compared to its variant $\mathrm{B}$.

Early death also shortens bulking time and limits overall productivity of potato [15]. The decrease in the amount of stems may be caused by accelerated early ripening planting tubers, which might then lead to a reduction in both the assimilation area and the harvesting of potato plants [16]. In case of less developed shrub, the tuberization processes grow faster [17], and the more developed tubers have a relatively lower post-harvesting resting stage [18]. At end of storage the height of stolons of the variant $\mathrm{A}$ of variety Domodedovskiy was $1.5-2$ times as much in spring as compared to its variant B. This showed that the high infection rate in sowings stimulates accelerated development and early die-off of potato plants. Therefore it is most probable that the lack of reasonable differences of the leaf DF parameters in the flowering stage between the variants A and B of varieties (Table 1) can be resulted mainly both from the ontogenetic development rate and the well known active PSII concentration reduction [5-8], which further promotes emergence of significant distinctions of leaf DF only in the end of the vegetation period. So, at this period of each a variants I was higher and $\tau$ was lower compared to their B variants (Table 1). Simultaneously, I was higher and $\tau$ was lower in case of $\mathrm{N}$ decreasing in a plant (Tables 2 and 3). These DF parameters differences could be stipulated a well known reduction in active PSII content by virus infections and inhibition of carbohydrate metabolism [5-8]. DF parameters typical

Table 1. Influence of Virus Infection on DF Parameters of Potato*.

\begin{tabular}{|c|c|c|c|c|c|c|c|c|}
\hline Variety & $\begin{array}{c}\text { Phenological } \\
\text { Stage }\end{array}$ & Variant & $\begin{array}{c}\text { Registration } \\
\text { Data }\end{array}$ & $\begin{array}{c}\text { Plants } \\
\text { Quantity }\end{array}$ & I in rel. units & $\mathrm{I}_{\mathrm{A}} / \mathrm{I}_{\mathrm{B}}$ & $\tau$ in $\mathrm{s}$ & $\tau_{\mathrm{A}} / \tau_{\mathrm{B}}$ \\
\hline \multirow{3}{*}{ Domodedovskii } & \multirow{2}{*}{ Flowering } & $\begin{array}{l}\mathrm{A} \\
\mathrm{B}\end{array}$ & June 9 & $\begin{array}{l}65 \\
78\end{array}$ & $\begin{array}{l}122.4 \pm 3.4 \\
112.9 \pm 3.1\end{array}$ & 1.084 & $\begin{array}{l}28.1 \pm 0.4 \\
30.6 \pm 0.5\end{array}$ & 0.920 \\
\hline & & $\begin{array}{l}\text { A } \\
\text { B }\end{array}$ & June 13 & $\begin{array}{l}46 \\
30\end{array}$ & $\begin{array}{l}120.8 \pm 3.6 \\
111.0 \pm 3.8\end{array}$ & 1.088 & $\begin{array}{l}29.6 \pm 0.6 \\
29.0 \pm 0.7\end{array}$ & 1.021 \\
\hline & Harvesting & $\begin{array}{l}\mathrm{A} \\
\mathrm{B}\end{array}$ & July 6 & $\begin{array}{l}60 \\
70\end{array}$ & $\begin{array}{l}119.8 \pm 5.3 \\
157.5 \pm 5.0\end{array}$ & 0.761 & $\begin{array}{l}26.2 \pm 0.7 \\
24.8 \pm 0.8\end{array}$ & 1.056 \\
\hline \multirow{2}{*}{ Lork } & Flowering & $\begin{array}{l}\mathrm{A} \\
\mathrm{B}\end{array}$ & August 13 & $\begin{array}{l}39 \\
22\end{array}$ & $\begin{array}{l}70.4 \pm 2.0 \\
73.1 \pm 5.3\end{array}$ & 0.963 & & \\
\hline & Harvesting & $\begin{array}{l}\mathrm{A} \\
\mathrm{B}\end{array}$ & September 9 & $\begin{array}{l}25 \\
25\end{array}$ & $\begin{array}{l}71.4 \pm 3.2 \\
80.5 \pm 3.5\end{array}$ & 0.887 & & \\
\hline \multirow{2}{*}{ Belorussian earlier } & \multirow{2}{*}{ Harvesting } & $\begin{array}{l}\text { A } \\
\text { B }\end{array}$ & October 3 & $\begin{array}{l}183 \\
184\end{array}$ & $\begin{array}{l}81.9 \pm 0.7 \\
92.8 \pm 0.7\end{array}$ & 0.889 & & \\
\hline & & $\begin{array}{l}\text { A } \\
\text { B }\end{array}$ & October 17 & $\begin{array}{l}65 \\
86\end{array}$ & $\begin{array}{l}76.0 \pm 3.3 \\
87.8 \pm 2.1\end{array}$ & 0.866 & & \\
\hline
\end{tabular}

*For the variant $A$ of the variety Domodedovskiy, the amount of infected plants was $58 \%$ (viruses $\mathrm{X}-46 \%, \mathrm{~S}-6 \%, \mathrm{M}-25 \%$ and $\mathrm{Y}-5 \%$ ), and for the variant $\mathrm{B}-5 \%$ (viruses $\mathrm{X}-5 \%, \mathrm{~S}-1,2 \%$ and $\mathrm{M}-2,6 \%$ ). Accordingly, for the plants of the variety Lork, was $18 \%$ (viruses $\mathrm{X}-$ $7.7 \%, \mathrm{~S}-7.7 \%$ and $\mathrm{M}-10.3 \%$ ) and $2 \%$ (virus $\mathrm{X}-2 \%$ ), and for those of the variety Byelorussian Early - 52\% (viruses $\mathrm{X}-42 \%, \mathrm{~S}-7 \%, \mathrm{M}-$ $11 \%$ and $\mathrm{Y}-2 \%$ ) and $30 \%$ (viruses $\mathrm{X}-24 \%, \mathrm{~S}-4 \%$ and $\mathrm{M}-5 \%$ ), respectively. 
Table 2. Influence of combined virus infection on DF and productivity of the potato variety Pirmunes.

\begin{tabular}{ccccc}
\hline $\begin{array}{c}\text { Quantity } \\
\text { of Strain }\end{array}$ & $\begin{array}{c}\text { Quantity } \\
\text { of Plant }\end{array}$ & I in rel. units $\tau$ in seconds & $\begin{array}{c}\text { Productivity } \\
\text { per plant in g }\end{array}$ \\
\hline 0 & 27 & $149.2 \pm 5.1$ & $23.10 \pm 0.73$ & $435 \pm 35$ \\
1 & 35 & $132.8 \pm 5.6$ & $23.28 \pm 0.68$ & $374 \pm 32$ \\
2 & 19 & $124.9 \pm 6.2$ & $25.14 \pm 1.31$ & $277 \pm 28$ \\
\hline
\end{tabular}

Table 3. Influence of combined virus infection on DF of the potato variety Domodedovskiy.

\begin{tabular}{cccc}
\hline $\begin{array}{c}\text { Quantity } \\
\text { of Strain }\end{array}$ & $\begin{array}{c}\text { Quantity } \\
\text { of Plant }\end{array}$ & I in relative units & $\tau$ in seconds \\
\hline 0 & 53 & $153.9 \pm 7.6$ & $25.38 \pm 0.60$ \\
1 & 49 & $149.3 \pm 7.6$ & $24.96 \pm 0.76$ \\
3 & 8 & $114.9 \pm 13.0$ & $27.00 \pm 2.27$ \\
\hline
\end{tabular}

changes correlated with yield reduction for the stronglyinfected variants and in case of the number of virus strains increased in plant (Tables 1, 2 and 4). This confirmed the previous conclusion that the combined virus infection induces more significant fall in yield of potato $[1,2]$.

During the experiment, the interaction between the key LR and DR centers may induce I and $\tau$ changes $[13,14]$. The elimination of $\tau$ values influences could eliminate the DR affect on I [13,14]. During the experiment, the accumulation of changes in active PSII concentration in the end of the vegetation period was indicated by the reduced ratio of $\mathrm{I}_{\mathrm{A}} / \mathrm{I}_{\mathrm{B}}\left(\mathrm{r}_{\mathrm{IA} / \mathrm{IB} T}=-0.989\right)$, the correspondence of which was significant in case of eliminating the effect of the degree of interaction between LR and DR $\left(\mathrm{r}_{\mathrm{IA} / \mathrm{IB}} \mathrm{T}(\tau \mathrm{A} / \tau \mathrm{B})=-1.000\right)$ (Table 1). In the event of eliminating $\tau$ influence I reduction significance correlated with the $\mathrm{N}$ increase in plant and yield decrease (Table 4).

The observed correspondences allow us to develop a new method of clone selection of virus-free seed potatoes. For this goal, an independent Industrial Test was performed via the primary selection of the first spring planting batches of Byelorussian early variety, based on the I values of leaves of 500 plants (degree of virus infection of crop was $33 \%$ ). Its average I value was $97.7 \pm$ 0.4 rel. units. For 50 plants of the variant 1 and 50 plants of the variant 2 selected from these 500 plants, I was $153.8 \pm 2.1$ and $58.6 \pm 1.2$ rel. units, respectively. The average productivity of the plant for 1 and 2 variants was 820 and 600 g per plant, respectively, which may also indicate the lower infection level of plants of the variant 1 as compared with the variant 2 . The tubers of these selected variants were planted out in summer both alongside the nearby field industrial reproduction, and in an isolated plot. In field conditions the degree of virus infection for the reproduction of plants grown from the tuber of the variant 1 was less on $15 \%$ and $22 \%$ compared with industrial plants of second reproduction and the tubers of variant 2, respectively, (Table 5). In the isolated plot, the infection degree of plants grown from the tubers of the variants 1 and 2 was lowered to 4 and $6 \%$, respectively, as compared with these values obtained in the industrial field conditions (Tables 5 and $\mathbf{6}$ ). It agrees with the well known reduction of the infection transfer probability in the isolated plot [2]. At the end of the vegetation period I of variant 1 was higher on $16 \%$ compared variant 2 (Table 5). These results also indicate the lower infection rate of plants by the variant 1 as compared with the industrial and variant 2 sowings.

For the tuber-grown plants of the variant 1 being cultivated both in industrial fields and isolated plots, the height of batches was higher by $7.2-9.1 \%$, and the quantity of stems per batch was more by $28.8-32.8 \%$ compared with the plants being cultivated from tubers of the variant 2 (Tables 5 and 6). This also indicates a virus infection lower degree in plants grown from tubers of the variant 1, as well as rate of yield (Table 5).

The amplitude I for the leaves of 180 batches of this reproduction of the variant 1 was measured before harvesting, which amounted to an average of $92.0 \pm 2.1$ rel. units. For 45 selected batches, the amplitude I was, on

Table 4. Correlative correspondence between parameters of DF, number of strain in plant and yield of the potato varieties Pirmunes and Domodedovskiy.

\begin{tabular}{ccccc}
\hline Coefficient Description & Pirmunes & Domodedovskiy & Coefficient Description & Pirmunes \\
\hline$r_{\mathrm{IN}}$ & -0.980 & -0.975 & $\mathrm{r}_{\mathrm{IP}}$ & 0.968 \\
$\mathrm{r}_{\tau \mathrm{N}}$ & 0.903 & 0.867 & $\mathrm{r}_{\tau \mathrm{P}}$ & -0.926 \\
$\mathrm{r}_{\mathrm{I} \tau}$ & -0.800 & -0.954 & $\mathrm{r}_{\mathrm{IP}(\tau)}$ & 1.000 \\
$\mathrm{r}_{\mathrm{IN}(\tau)}$ & -1.000 & -1.000 & $\mathrm{r}_{\mathrm{NP}}$ & 0.998 \\
\hline
\end{tabular}

*The critical value of the correlation coefficient at $5 \%$ significance level is 0.997. 
Table 5. Description of field reproduction results in case of using the DF for selection of potato planting materials.

\begin{tabular}{ccccccc}
\hline Variant & $\begin{array}{c}\text { Quantity of } \\
\text { Plants }\end{array}$ & $\begin{array}{c}\text { Virus Infection } \\
\text { Degree in } \%\end{array}$ & $\begin{array}{c}\text { I in relative } \\
\text { units }\end{array}$ & $\begin{array}{c}\text { Batch Height } \\
\text { in cm }\end{array}$ & $\begin{array}{c}\text { Stems Quantity per } \\
\text { batch in items }\end{array}$ & $\begin{array}{c}\text { Yield per } \\
\text { batch in } \mathrm{g}\end{array}$ \\
\hline Industrial & 180 & 45 & & & & 342 \\
Variant 1 & 180 & 30 & $87.8 \pm 0.7$ & $44.4 \pm 0.5$ & $2.35 \pm 0.06$ & 449 \\
Variant 2 & 88 & 52 & $76.0 \pm 3.3$ & $41.4 \pm 0.8$ & $1.77 \pm 0.07$ & 330 \\
\hline
\end{tabular}

Table 6. Description of isolated plots reproduction results in case of using the DF for selection of potato planting materials.

\begin{tabular}{ccccc}
\hline Variant & Quantity of Plants & $\begin{array}{c}\text { Virus Infection } \\
\text { Degree in \% }\end{array}$ & $\begin{array}{c}\text { Batch Height in cm } \\
\text { Quantity of Stems per } \\
\text { batch in items }\end{array}$ \\
\hline Variant 1 & 37 & 26 & $34.8 \pm 1.3$ & $2.86 \pm 0.15$ \\
Variant 2 & 21 & 46 & $31.9 \pm 1.3$ & $1.77 \pm 0.15$ \\
\hline
\end{tabular}

average, $132.0 \pm 3.4$ rel. units. In the second spring field reproduction the selected planting tubers from 45 batches, as well as the harvesting industrial tubers were planted out in three repetitions per 50 items. The productivity of the plant grown from the selected planting materials of 45 batches amounted, on the average, to 750 $\mathrm{g}$, while the batch yield for the industrial field variant was $583 \mathrm{~g}\left(\mathrm{LSD}_{05}=21 \mathrm{~g}\right)$. Hence, these industrial tests showed that the selection at the end of the vegetation of planting materials by leaves amplitude I will ensure a $26.4 \%$ of additional yield.

\section{DISCUSSION}

The data show that the well known damage of nitrogen metabolism in plants, induced by mosaic viruses $[1,2$, $5,19,20]$, remarkably affected the DF parameters. The distinctions of strongly and weakly infected plants grow higher particularly in case of a combined virus infection. Virus infection induces acceleration of plants development and their early dying, both I decrease and $\tau$ increase in the end of vegetation, reduction in the amount of stems, plants' height and assimilatory area surface as well as yields. Analogous changes of plant morphology and yield was registered also in other reports $[5,7,19]$. This allows us recommended the use of DF I for selecting virus-free planting materials. On other hand, after the infection of cotton-plant by fungus Verticillum resulting from continuous development of virus disease, a decrease in I was also observed [21]. Therefore this allows us to assume that the use of parameters DF can find a broader application. The use of the new method enables to select potato tubers as much as possible free from diseases, thereby raising the industrial yield of the potato reproductions. Therefore this biophysical method may be recommended also to be applied in small farms. One of the most noteworthy advantages of this method is its easy-to-apply technology based on the use of up-to-date portable phosphoroscopes.

Under continuous influence of virus infection, changes in the DF parameters were observed analogously, caused by water stress on potato, modified by doses of phosphorus fertilizers [13], leaf prolonged dehydration and frosts influence [14], which also being correlated with the changes of yield. Therefore, these results allow recommend the use of DF parameters in the systems analysis of production process.

\section{ACKNOWLEDGEMENTS}

Author thanks Dr. A. Sahakyan for assistance in serological analysis.

\section{REFERENCES}

[1] Salazar, L. F. (1982) Virus detection in potato seed production. Technical information Bulletin, 18. http://www. cipotato.org/ library/pdfdocs/TIBen21141.pdf

[2] Zikin, A. G. (1976) Viral Diseases of the Potato. Sankt Petersburg, Kolos.

[3] Avagyan, A. B. and Sahakyan, A. D. (1987) About a degree of reliability of serological method using for diagnostics of potato virus diseases in hot climate conditions. Russian Agricultural Biology, 8, 63-64.

[4] Avagyan, A. B. and Sahakyan, A. D. (1991) Diagnostics of mosaic viruses in potato plants by the use of serological method. Russian Agricultural Biology, 3, 123-127.

[5] Chia, T. F. and He, J. (1999) Photosynthetic capacity in Oncidium (Orchidaceae) plants after virus eradication. Environmental and Experimental Botany, 42, 11-16.

[6] Zhou, Y. H., Peng, Y. H., Lei, J. L., Zou, L. Y., Zheng, J. H. and Yu, J. Q. (2004) Effects of potato virus $\mathrm{Y}^{\mathrm{NTN}}$ infection on gas exchange and Photosystem II function in leaves of Solanum tuberosum L. Photosynthetica, 42, 417-423.

[7] Guo, D. P., Guo, Y. P., Zhao, J. P., Liu, H., Peng, Y., Wang, Q. M., Chen, J. S. and Rao, G. Z. (2005) Photosynthetic rate and chlorophyll fluorescence in leaves of stem mustard (Brassica juncea var. tsatsai) after turnip 
mosaic virus infection. Plant Science, 168, 57-63.

[8] Synkova, H., Semoradova, S., Schnablova, R., Muller, K., Pospísilova, J., Ryslava, H., Malbeck, J. and Serovska, N. (2006) Effects of biotic stress caused by Potato virus Y on photosynthesis in ipt transgenic and control Nicotiana Tableacum L. Plant Science, 171, 607-616.

[9] Mar, T., Brehlner, J. and Roy, G. (1975) Induction kinetics of delayed light emission in spinach chloroplasts. Biochimica et Biophysica Acta, 376, 345-353.

[10] Wraight, C. A. and Crofts, A. R. (1971) Delayed fluorescence and the high-energy state of chloroplast. European Journal of Biochemistry, 19, 386-397.

[11] Goltsev, V., Zaharieva, I., Lambrev, P., Yordanov, I. andStrasser, R. (2003) Simultaneous analysis of prompt and delayed chlorophyll a fluorescence in leaves during the induction period of dark to light adaptation. Journal of Theoretical Biology, 225, 171-183.

[12] Goltsev, V., Chernev, P., Zaharieva, I., Lambrev, P., Strasser, R. J. (2005) Kinetics of delayed chlorophyll a fluorescence registered in milliseconds time range. Photosynthesis Research, 84, 209-215.

[13] Avagyan, A. B. (2010) Correlations between Delayed Fluorescence of Chlorophyll, Metabolism and Yield of Plants. I. Influence of Fertilizers on Correlations. Journal of Biophysical Chemistry, 1. (in press)

[14] Avagyan, A. B. (2010) Correlations between Delayed Fluorescence of Chlorophyll, Metabolism and Yield of Plants. II. Influence of Moisture of Leaf and Temperature Condition on Delayed Fluorescence of Leaves. Journal of Biophysical Chemistry, 1. (in press)
[15] Dwelle, R.B. and Love, S. L. (2009) Potato Growth and Development. University of Idaho. http://www.ag.uidaho. edu/potato/production/files/Growth\%20and\%20Development $\% 20$ chapter-\%20web.pdf

[16] Tucci, R.D. (1966) Influence of steams development at planting on the subsequent growth and a crop of tubers. In: Growth and Development of a Potato, Moscow, 107126.

[17] Milthorp, F. L. (1989) Growth of the potato. In: Burton, W. G. Ed., The potato, Longman Scientific \& Technical. 189-284.

[18] Burton, W. G. (1989) Representations about a dormant period of tubers and its mechanism. In: Burton, W. G. Ed The potato, 3rd Edition, Longman Scientific \& Technical, 31-59.

[19] Kobayashi, K., Sarrobert, C., Ares, X., Rivero, M. M., Maldonado, S., Robaglia, C. and Mentaberry, A. (2004) Over-expression of potato virus X TGBpl movement protein in transgenic tobacco plants causes developmental and metabolic alterations. Plant Physiology and Biochemistry, 42, 731-738.

[20] Ayako, Y. K., Shinpei, K., Hirofumi, Y., Noriyuki, D. and Kazuhito, K. (2006) Nitrate reductase is responsible for elicitin-induced nitric oxide production in Nicotiana benthamiana. Plant \& Cell Physiology, 47, 726-735.

[21] Makarova, E. N., Abrarov, A. A., Veselovskiy, V. A. and Vecelova, T. V. (1980) Delayed light of cotton leave depending from wilt resistance. Russian Plant Physiology, 27, 413-418.

\author{
Abbreviations: \\ LR - light reactions of photosynthesis \\ DR - dark reactions \\ PSII - photosystem II \\ DF - delayed fluorescence of leaf chlorophyll \\ I - maximum amplitude of DF
}

$\tau$ - time of I half decrease
$\mathrm{T}$ - vegetation period
$\mathrm{N}$ - quantity of virus strains in plant
$\mathrm{P}$ - yield
$\mathrm{r}$ - correlation coefficient 